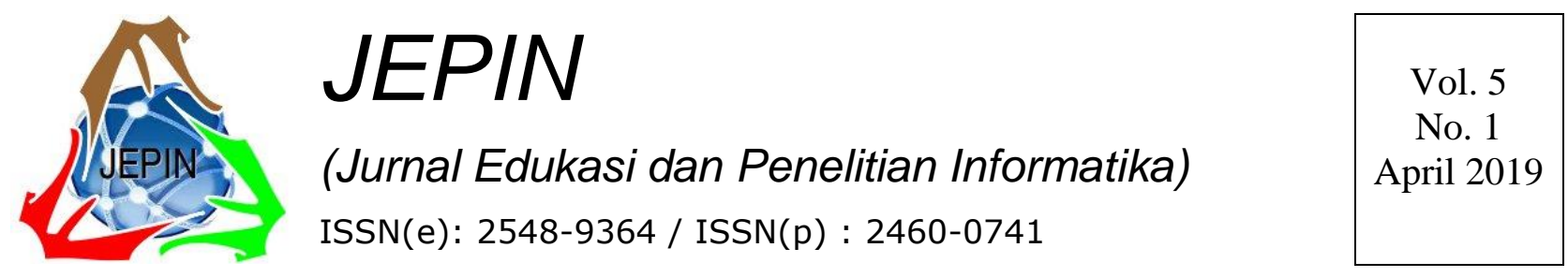

\title{
Reverse Engineering untuk Analisis Malware Remote Access Trojan
}

\author{
Aldy Putra Aldya ${ }^{\# 1}$, Nur Widiyasono ${ }^{\# 2}$, Tesa Pajar Setia ${ }^{\# 3}$ \\ \#Jurusan Informatika, Fakultas Teknik, Universitas Siliwangi, \\ Jln. Siliwangi no 24, Kota Tasikmalaya, 46115, Indonesia \\ 1aldy@unsil.ac.id \\ ${ }^{2}$ nur.widiyasono@unsil.ac.id \\ 3 tesa.paja14@student.unsil.ac.id
}

\begin{abstract}
Abstrak- Para hacker menggunakan malware Remote Access Trojan untuk merusak sistem kemudian mencuri data para korbannya. Diperlukan analisis mendalam mengenai malware baru-baru ini karena malware dapat berkamuflase seperti sistem tidak dicurigai. Penggunaan teknik basic analysis sangat tergantung pada perilaku malware yang dianalisis, analisis akan sulit ketika ditemukan malware baru yang menggunakan suatu teknik baru. Reverse engineering merupakan salah satu solusi untuk melakukan analisis malware karena menggunakan teknik reverse engineering kode pada malware dapat diketahui. Malware Flawed ammyy ini merupakan software yang disalahgunakan dari Ammyy Admin versi 3 oleh hacker TA505. Penelitian ini bertujuan untuk bagaimana alur untuk melakukkan identikasi malware kususnya malware RAT dengan teknik reverse engineering dan tools yang bias digunakan. Penelitian ini menggunakan metodologi deskriptif,. Hasil dari penelitian menunjukan bahwa alur untuk melakukan reverse engineering dan tools yang dapat digunakan.
\end{abstract}

Kata kunci- Flawed Ammyy, Reverse Engineering, Remote Access Trojan

\section{PENDAhUluan}

Internet dapat membantu seseorang memanfaatkan banyak layanan hanya dengan bantuan beberapa klik, dengan internet system yang begitu rumit menjadi lebih praktis, murah dan lain-lain [1]. Meningkatnya pengguna internet membuat kejahatan merambah ke dunia maya yang sering disebut sebagai cybercrime [2]. Cybercrime yang digunakan oleh penyerang semakin beragam dan kompleks. Serangan tersebut diantranya melibatkan malicious software atau yang biasa disebut malware yang merupakan suatu program jahat [3].

Beragam tujuan yang dimiliki para pelaku ini beberapa diantaranya adalah untuk melakukan aktifitas berbahaya yang berdampak sangat merugikan bagi para korbannya, antara lain seperti penyadapan serta pencurian informasi pribadi [4][5]. Beberapa malware berbahaya seperti Virus, Worm, Trojan Horse, juga bisa membuat Back Door yang dapat melakukan pencurian informasi pribadi atau mengambil kendali sistem yang telah terinfeksi [6].
Malware sering masuk ke sistem melalui file yang diunduh. Malware yang telah memasuki sistem, malware akan melakukan aktivitas dan merusak seluruh system [7].

Seorang investigator harus memiliki kemampuan untuk melakukan analisa malware dalam setiap melakukan investigasi. Meningkatnya sejumlah malware yang dapat berevolusi dan mampu beradaptasinya terhadap perangkat analisis yang selama ini digunakan sehingga sulit untuk dilakukan ananlisis [8]. Analisa malware dengan menggunakan Reverse engineering merupakan salah satu solusi yang bisa digunakan saat ini. Reverse engineering dalam analisis malware berguna untuk ekstraksi data yang memuat informasi yang ada didalam malware [9].

Para peneliti Proofpoint telah menemukan malware Trojan akses jarak jauh yang sebelumnya tidak terdokumentasi yang disebut Flawed ammyy rat [10]. Malware Flawed ammyy rat dibuat dari kode Ammyy admin versi versi 3 yang disalah gunakan. Ammyy admin merupakan perangkat lunak desktop jarak jauh yang digunakan jutaan konsumen dan bisnis untuk menangani remote control dan diagnosis pada platfom Windows [11]. Penyerang yang melakukan penyebaran malware Flawed ammyy rat merupakan kelompok peretas TA505 yang terkenal karena menyebarkan spam malware seperti Trojan Dridex perbankan, Locky ransomware, dan Jaff ransomware. [12]

Penelitian yang telah dilakukan sebagai dasar penelitian ini diantaranya Peneltian [1] telah dilakukan analisis statis dan analisis dinamis pada malware DrakComet. Hasil dari penelitian tersebut menguraikan metodologi yang efektif dan efisien yang dapat meningkatkan kinerja deteksi dan penghapusan malware yang dikumpulkan. Analisis dinamis merupakan cara terbaik untuk melakkan analisis sample sebuah malware.

Penelitian [13] menguraikan hasil komparasi terhadap metode analisis malware statis. Peneliti telah melakukan ekstraksi 11 vektor kelompok kecil untuk 600 malware, dan berhasil melakukan klasifikasi lebih dari setengah kode kedalam kelompok yang sesuai menggunakan vektor. Pemeriksaan yang cermat pada kode biner juga 
menegaskan bahwa vektor bit telah mengklasifikasikannya dengan cara yang benar. Hasil dari eksperimen menunjukkan bahwa bit vektor dapat digunakan secara efektif untuk melakukan analisis malware statis, dan vektor bit grup dapat membantu diklasifikasikan malwares kedalam kelompok yang sesuai.

Penelitian [9] telah melakukan proses reverse engineering pada malware Biscuit. Cara kerja malware tersebut adalah adanya auto request untuk koneksi ke ip address tertentu yaitu ip address 114.101.115.115. Selanjutnya proses reverse engineering melalui penulusuran perintah: bdkzt, ckzjqk, download, exe, exit dan lists telah dapat memetakan bagaimana cara kerja dari malware Biscuit.

Peneliti [14] telah melakukan reverse engineering untuk membongkar kode ransomware kemudian analisis lebih lanjut. Hasil dari penelitian tersebut menunjukkan meskipun penggunaan enkripsi tangguh, seperti ransomware lain yang menggunakan serangan dengan struktur dan kriptografi primitif. Analisis ini telah menuntun pada kesimpulan bahwa strain ransomware tidak serumit dilaporkan sebelumnya. Analisis praktis dan terperinci ini mencoba memberi kesadaran kepada komunitas bisnis tentang realitas dan Pentingnya keamanan TI, pencegahan, pemulihan dan keterbatasannya.

Peniliti [15] telah melaukan reverse engineering pada malware botnet. Tujuan utama dari penelitian ini meupakan untuk menentukan pendekatan yang paling memadai sebagai pencegahan dari insiden botnet. Gangguan jaringan pada proses ini merupakan aktivitas online ilegal dan pencurian data organisasi, ini dapat dicegah dan bahkan bot sistem Intrusion Prevention spesifik dapat dikembangkan. penelitian menjamin aliran data yang dikonfirmasi dalam ruang digital oleh komunikasi e-governance yang diasuransikan untuk setiap negara dari terorisme cyber.

Penelitian [16] melakukan reverse engineering pada malware Flawed ammyy rat. Hasil dari penelitian dengan analisis dinamis dan reverse engineering dengan menggunakan tahap disassembly menunjukkan pergerakan dari malware dimana malware ini tidak dapat berjalan pada sistem dalam kedaan mode DOS. Malware ini memanipulasi system dengan cara menjalankan aplikasi Ammyy Admin 3, karena Amyy Admin merupakan aplikasi yang aman maka memberi akses pada malware tersebut, kemudian malware menyimpan data korban dan melakukan singkron dengan ip address 103.208.86.69.

Malware RAT ini tidak cukup hanya dilakukan dengan teknik basic analysis malware karena tidak semua malware rat ini berjalan pada system. Malware rat ini harus terkoneksi dengan attacker sebagai tuan yang melakukan perintah selanjutnya, seperti mengaktifkan keyloger, menggerakkan pointer korban, bahkan dapat mengaktifkan webcam korban tanpa sepengtahuan. Melakukan hal tersebut system mesti terhubung dengan suatu jaringan, namun untuk melakukan basic analysis malware diperlukan system yang steril, tidak terhubung dengan internet karena dapat menyebabkan penyebaran malware melalui jaringan. Beda halnya dengan malware bonet virus worm ransomware dan lain-lain yang dapat melakukan eksekusi sesuai dengan arsitektur yang telah dibuat.

Tujuan dari penelitian ini untuk melengkapi penelitian [16] dimana penelitian tersebut hanya menggunakan 1 tahap reverse engineering disassembly, untuk penelitian kali ini akan menggunakaan tahapan lainnyan seperti identifikasi sample malware untuk mengetahui type file malware, hitung nilai hash untuk megetahui nilai hash pada malware, dan string analysis untuk mengetahui apakah function yang didapat dari teknik disassembly itu sesuai atau ada function lain yang tidak terdefinisi dengan teknik disassembly. Kemudian menguraikan alur untuk melakukan reverse engineering khususnya malware Remote Access Trojan dan rekomendasi tools yang dapat digunakan untuk melakukann reverse engineering malware RAT.

\section{MetodologI}

Metodologi yang digunakan pada penelitian ini menggunakan metodologi deskriptif untuk menjelaskan bagaimana proses penelitian. Melakukan reverse engineering dilakukan beberapa tahapan seperti pada gambar 1:

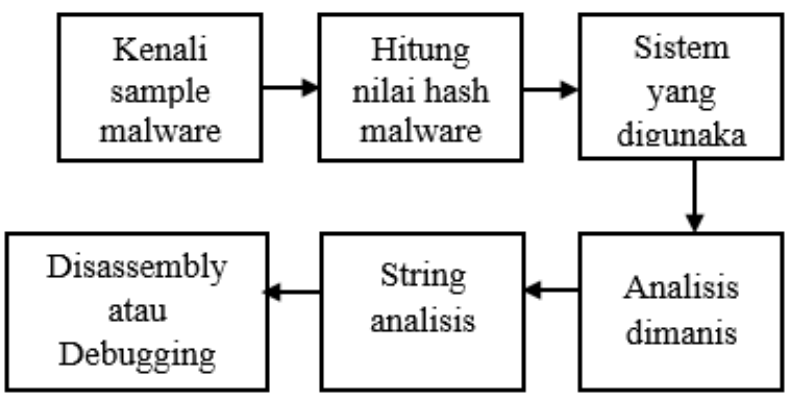

Gambar. 1 Alur reverse engineering

A. Kenali sample malware

Tahap setelah mendapatkan sample malware identifikasi type file seperti apa malware tersebut. Ini diperlukan untuk menetukan sistem yang bagaimana digunakan nanti dalam melakukan analisis dinamis.

B. Hitung nilai hash sample malware

Hash dari sebuah program memiliki identitas seperti halnya sidik jari pada manusia, maka perlu dihitung sebagai bukti digital

\section{Sistem yang digunakan}

Tahap setelah mengetahui type file system yang akan dibangun disesuaikan dengan type file. Seperti type file sample malware executable sistem yang akan digunakan adalah Windows.

D. Analisis dinamis

Tahap analisis dinamis diperlukan untuk melihat pergerakan malware ketika dijalankan pada sistem. Penetian kali ini menggunkan teknik sandbox unuk melakukan analisis dinamis 


\section{E. String analysis}

Tahap string analisis menampilkan nilai yang akan dilakukan proses load oleh sample malware ketika dieksekusi. Hal ini yang menjadikan dalam proses reverse engineering harus dilakukan string analisis untuk mendapatkan bukti kuat dari sample malware.

F. Disassembly atau debugging

Tahap ini malware akan dibuka source kode yang terdapat pada malware tersebut. Teknik disassembly merupakan teknik reverse engineering untuk menerjemahkan dari bahasa mesin ke bahasa yang mudah dimengerti manusia. Debugging digunakan untuk melakukan pengujian dari setiap proses inti yang ada didalam malware. Penelitian kali ini cukup menggunakan disassembly.

TABEL I TOOLS UNTUK REVERSE ENGINEERING

\begin{tabular}{|c|l|}
\hline Tools & \multicolumn{1}{|c|}{ Keterangan } \\
\hline Virustotal & $\begin{array}{l}\text { Digunakan untuk mengtahui } \\
\text { informasi mengenai sample } \\
\text { malware }\end{array}$ \\
\hline Hashmyfile & $\begin{array}{l}\text { Digunakan untuk menghitung nilai } \\
\text { hash }\end{array}$ \\
\hline Hybrird analysis & Digunakan untuk sandbox online \\
\hline Bintext & Digunakan untuk string analysis \\
\hline Ida pro & $\begin{array}{l}\text { Digunakan untuk disassembly atau } \\
\text { debugging }\end{array}$ \\
\hline
\end{tabular}

\section{HASIL DAN PEMBAHASAN}

A. Kenali sample malware

Tahap ini menggunakan tools virustotal untuk mendaptakan informasi mengenai sample malware yang didapat. Sample malware yang didapat diunggah pada website virustotal. Hasil unggahan malware pada website virustotal dapat dilihat pada gambar 2 .

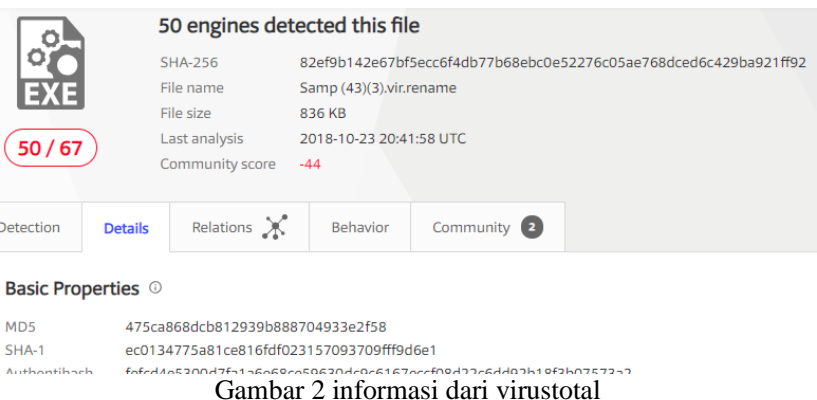

Informasi yang didapat mengenai sample malware adalah type file malware merupakan file executable dengan size file $836 \mathrm{~kb}$ kemudian dari 67 anti virus 50 diantaranya menaytakan bahwa sample malware berbahaya dengan kategori Trojan.

B. Hitung nilai hash sample malware

Melakukan penghitungan hash sample malware yang didapat gunakan tools hashmyfile. Buka aplikasi hashmyfile klik File, kemudian klik Add File, lalu pilih file sample malware, setelah itu open file. Hasil dari perhitungan hash sample malware dapat dilihat pada gambar 3

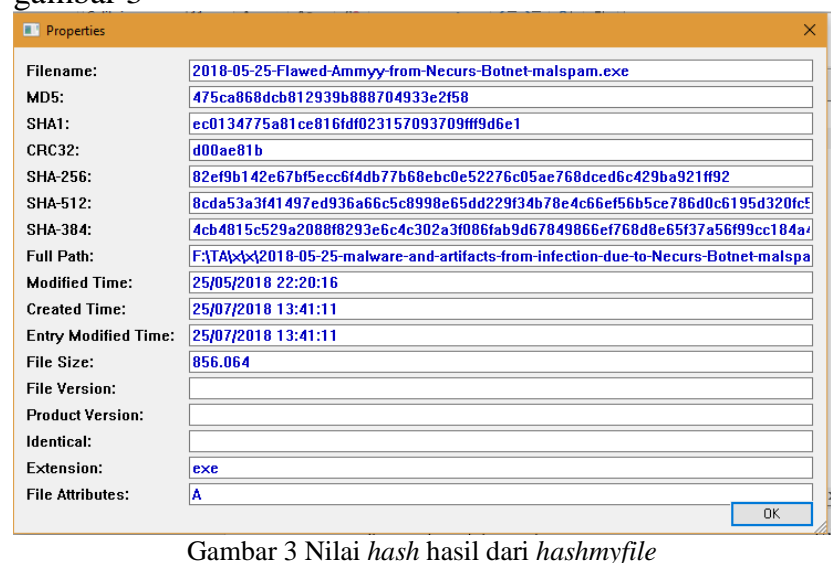

Gambar 3 menunjukan nilai hash dari sample malware sama dengan nilai hash md5 malware flawed ammy rat adalah 475ca868dcb812939b888704933e2f58 dengan demikian sample malware yang didapat merupakan file asli.

C. Sistem yang digunakan

Type file sample malware merupakan executable untuk melakukan analisis dinamis menggunakan system operasi windows, untuk memudahkan pergerakan malware dipilih windows 7 32bit dengan jaringan TOR ini digunakan untuk menghindari celah perekaman sidik jari pada jaringan eksternal.

\begin{tabular}{|l|l|}
\multicolumn{2}{c}{ TABEL II SPESIFIKASI VIRTUAL } \\
\hline Aplikasi VM & Sandbox online \\
\hline Sistem operasi & Windows 7 \\
\hline Jaringan & Jaringan TOR \\
\hline
\end{tabular}

\section{Analisis dinamis}

Virtual mesin sandbox online digunakan untuk melakukan analisis dinamis malware. Tools yang digunakan adalah hybrid analysis. Sample malware diunggah ke website hybrid analysis, kemudian pilih sistem yang ingin digunakan setelah itu buka hasil report hybrid analysis.

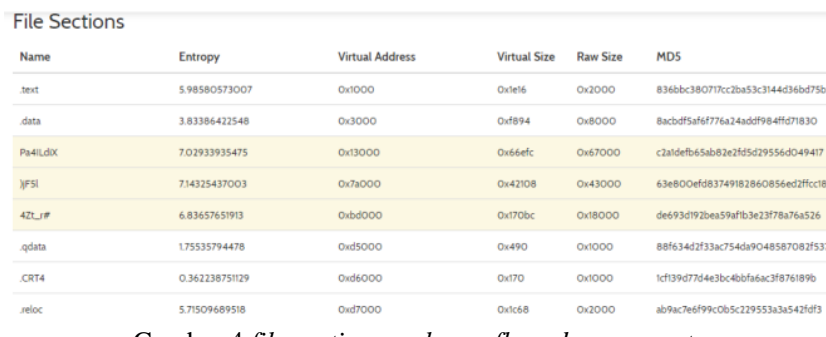

Merujuk gambar 4 terdapat 8 file sections setelah malware flawed ammyy rat dijalankan pada hybrid analysis dintaranya .text, .data, Pa4Ldix, )F51, 4Zt_r\#, .qdata, .CRT4, dan -reloc 
File Imports

GDI32.dll KERNEL32.dll ntdll.dl RASAPI32.dll SHLWAPI.dll USER32.dll
GetBrushOrgEx

\section{Screenshots}

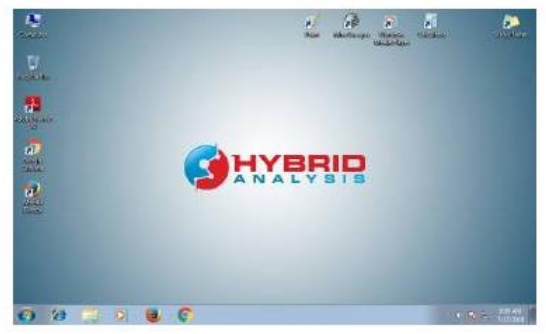

Gambar. 5 File import malware flawed ammyy rat

Merujuk pada gambar 5 malware melakukan beberapa import beberapa file pada sistem yang telah terinfeksi. File GDI32.dll untuk mengaktifkan function GetBrushOrgEX. File KERNEL32.dll untuk mengaktifkan function AreFileApisaANSI, GetBinaryTypeA, GetCompressedFileSizeA, GetModuleFileNameA, GetModuleHandlaA, SetFileApisToANSI. File ntdll.dll untuk mengaktifkan memset. File RASAPI32.dll untuk mengaktifkan function RasRenameEntryA. File SHLWAPI.dll tidak ada function yang diaktifkan. File USER32.dll untuk mengaktifkan function LoadMenuW. Network Analysis

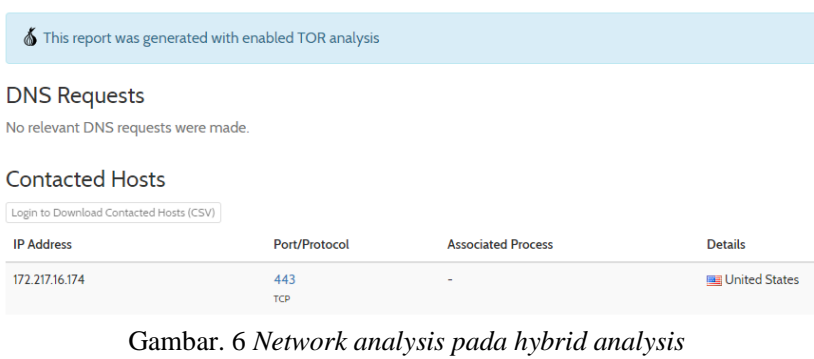

Merujuk gambar 6 hasil analisis jaringan dengan mengaktifkan TOR analysis menunjukkan bahwa malware melakukan koneksi dengan jaringan eksternal dengan ip address 172.217.16.174 dengan menggunakan port 443 dimana server tersebut berada di Amerika Serikat.

\section{E. String analysis}

Proses string analisis dilakukan pada karakter ASCII yang ada didalam program malware. Untuk melakukan string analisis digunakan program Bintext, seperti pada gambar 7

\begin{tabular}{|c|c|c|c|}
\hline File pos & Mem pos & ID & Text \\
\hline A $0000000 \mathrm{CD} 39 \mathrm{C}$ & $00000040539 C$ & 0 & GetCompressedFileSizeA \\
\hline A $0000000 \mathrm{CD} 3 \mathrm{~B} 6$ & $0000004053 B 6$ & 0 & AreFileApisANSI \\
\hline A $0000000 \mathrm{CD} 3 \mathrm{C} 8$ & $0000004053 \mathrm{C} 8$ & 0 & SetFileApisT $\alpha A N S I$ \\
\hline $\boldsymbol{A} 0000000 \mathrm{CD} 3 \mathrm{DC}$ & 0000004D53DC & 0 & SetFileApisT oOEM \\
\hline A $0000000 \mathrm{CD} 3 \mathrm{FO}$ & $0000004 D 53 F 0$ & 0 & GetModuleHandles \\
\hline A $0000000 \mathrm{CD} 404$ & 000000405404 & 0 & GetModuleFileNames \\
\hline A $0000000 \mathrm{CD} 41 \mathrm{~A}$ & $00000040541 \mathrm{~A}$ & 0 & GetBinaryTypeA \\
\hline A $0000000 \mathrm{CD} 42 \mathrm{~A}$ & $00000040542 \mathrm{~A}$ & 0 & KERNEL32.dII \\
\hline A $0000000 \mathrm{CD} 434$ & $00000040543 A$ & 0 & memset \\
\hline A $0000000 \mathrm{CD} 442$ & 000000405442 & 0 & ntdll.dll \\
\hline A $0000000 \mathrm{CD} 44 \mathrm{E}$ & $00000040544 \mathrm{E}$ & 0 & RasRenameEntryA \\
\hline A $0000000 \mathrm{CD} 45 \mathrm{E}$ & $00000040545 E$ & 0 & RASAPI32.dII \\
\hline A $0000000 \mathrm{CD} 46 \mathrm{E}$ & $00000040546 E$ & 0 & LoadMenu'W \\
\hline A $0000000 \mathrm{CD} 478$ & 000000405478 & 0 & USER32.dII \\
\hline
\end{tabular}

Gambar 7 String analysis menggunakan bintext

Gambar 7 menunjukkan bahwa hasil dari String analysis menggunakan bintext. Sring yang digunakan oleh malware flawed ammyy rat diantaranya GetBrushOrgEx, GetCompressedFileSizeA,

AreFileApisAnsi,

SetFileApisToANSI,

GetModuleHandleA,

SetFileApisToOEM,

GetBinaryType, memset, RasRenameEntryA, LoadMenuW

\section{F. Disassembly atau debugging}

Proses disassembly ini menggunakan tools IDAPro Setelah malware terbuka selanjutnya adalah melakukan analisa command yang ada didalam malware yang telah dilist di atas hasil dari dissaembly di tunjukan pada Gambar 8.

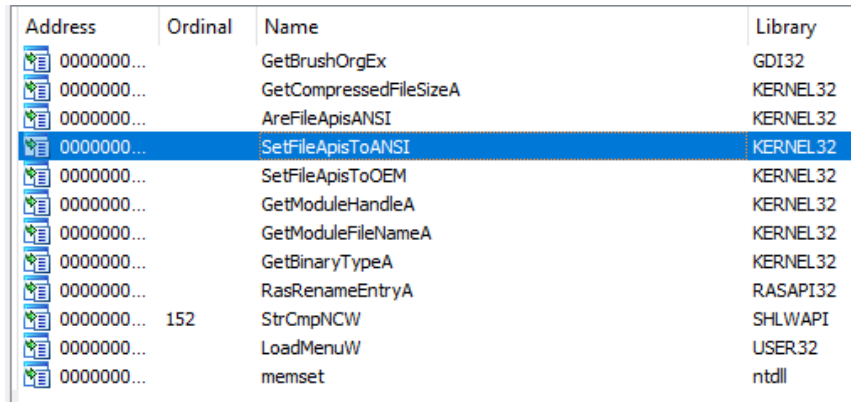

Gambar. 8 Hasil dissaembly menggunkan ida pro

BOOL stdcall Get GetBrushorgEX(HDC hdc, LPPOIN̄T lppt)

extrn GetBrushorgEx: dword

Malware memannggil function tersebut untuk mengambil alih fungsi pointer agar dapat mempermudah pencurian data.

DWORD_stdcall GetCompressedFileSizeA (LPCSTR IPFileName, LPDWORD

lpFilesizeHigh)

extrn GetCompressedFileSizeA: dword

Malware memanggil function tersebut untuk melakukan proceses compress file tertentu kemudian menyimpannya.

BOOL stdcall AreFileApisAnsi ()

extrn AreFileApisAnsi:dword

Perintah dengan function tersebut malware dapat menentukan apakah fungsi file I / O menggunakan halaman kode karakter ANSI atau OEM. 
Void stdcall SetFileApisToAnsi()

extrn SetFileApisToAnsi:dword

Function tersebut malware dapat membuat file I / O berfungsi untuk menggunakan halaman kode set karakter ANSI untuk proses saat ini. Fungsi ini berguna untuk operasi input dan output masukan 8-bit.

Void_stdcall SetFileApisToOEM()

extrn SetFileApisToOEM:dword

Function tersebut dapat membuat file I / O berfungsi untuk proses untuk menggunakan halaman kode karakter set $O E M$. Fungsi ini berguna untuk operasi input dan output masukan 8-bit.

HMDULE_stdcall GetModuleHandleA(LPCSTR lpModule Name)

extrn GetModuleHandleA:dword

Malware dengan function tersebut memilih file yang memenuhi syarat yang mengandung modul tertentu.

DOWRD stdcall

GetModūleFileNameA (HMODULE hModule,

LPSTR lpFilename, DOWRD nSize)

extrn GetModuleFileNameA: dword

Malware dengan menggunakan function tersebut dapat meneangani modul yang telah ditentukan

BOOL_stdcall GetBinaryTypeA(LPCSTR

lpApplictionName, LPDWORD lpBinaryType)

extrn GetBinaryTypeA: dword

Function tersebut malware dapat menentukan apakah file dapat di eksekusi, jika subsistem mana yang menjalankan file yang dapat dieksekusi

DWORD stdcall RasRenameEntryA (LPCSTR, LPCSTR LPCSTR)

extrn RasRenameEntryA: dword

Malware dengan function RasRenameEntry dapat mengubah nama entri di buku telepon.

extrn StrCmpNCW: dword

Malware dapat membandingkan nomor spesifik sejumlah karakter dari awal dua string menggunakan $\mathrm{C}$ run-time (ASCII)

HMENU stdcall LoadMenuW(HINSTANCE

hInstañce, LPCWSTR lp MenuName)

extrn RasRenameEntryA: dword

Malware dapat memuat sumber daya menu yang spesifik dari file yang dapat executable (.exe) yang terkait dengan instance aplikasi.

void_cdecl memset (void *Dst, int Val, size $\bar{t}$ Size)

extrn̄_imp_memset:dword

Malware melakukan setel buffer ke karakter yang ditentukan

Hasil dari reverse engineering malware flawed ammyy rat menunjuan bagimana pergerkan dari malware tersebut. Malware ternyata melakukan koneksi dengan jaringan eksternal dengan ip address 172.217.16.174. malware memiliki beberapa file section diantaranya .text, .data, Pa4Ldix, )F5l, 4Zt_r\#, .qdata, .CRT4, dan.relockemdian malware meliki file import File GDI32.dll untuk mengaktifkan function GetBrushOrgEX. File
KERNEL32.dll untuk mengaktifkan function AreFileApisaANSI, GetBinaryTypeA, GetCompressedFileSizeA, GetModuleFileNameA, GetModuleHandlaA, SetFileApisToANSI. File ntdll.dll untuk mengaktifkan memset. File RASAPI32.dll untuk mengaktifkan function RasRenameEntryA. File SHLWAPI.dll tidak ada function yang diaktifkan. File USER32.dll untuk mengaktifkan function LoadMenuW.

\section{KESIMPULAN}

Penelitian ini yang berjudul "Reverse Engineering Untuk Analisis Malware Remote Access Trojan" berdasarkan penelitian sebelumnya yang telah di lakukan, sehingga dapat disimpulkan sebagai berikut:

Tahapan untuk melakukan reverse engineering pada suatu malware kususnya malware RAT adalah sebagai berikut: kenali sample malware menggunakan tools virustotal, hitung nilai hash sample malware menggunakan tools hashmyfile, tentukan sistem yang digunakan untuk melakukan analisis dinamis, monitoring pergerakan malware dengan menggunakan metode analisis dinamis basic atau dapat menggunakan sandbox untuk sandbox online dapat menggunakan tool hybrid analysis, string analysis malware tersebut untuk memperkuat bukti dengan menggunakan tools bintext, terkhir lakukan disassembly atau debugging pada sample malware untuk membuka source malware tersebut gunakan tools ida pro.

Metode reverse engineering dengan teknik string analysis berhasil menunjukkan 12 function yang terdapat pada sample malware flawed ammyy rat ini menunjukkan bahwa penelitain sebelumnya telah menunjukkan hasil reverse engineering dengan disassembly telah terindentifikasi tidak ada function yang terlewat, jadi sebaiknya untuk melakukan reverse engineering sebaiknya dilakukan terlebih dahulu string analysis untuk mengetahui function atau mengetahui proses load dari malware kemedian dilakukan disassembly untuk mengetahui source kode yang terdapat pada malware. Metode sandbox online menunjukkan file section dan file import dari malware tersebut.

\section{UCAPAN TERIMA KASIH}

Pertama penulis mengucapkan bersyukur kepada Allah swt, karena berkat rahmat dan barokahnya penulis dapat menyelesaikan penelitian ini. Penulis mengucapkan terimakasih kepada para pembimbing yang sabar mengajarkan dan membimbing penulis, kepada orang tua atas segala dukungan dalam bentuk apapun serta pada pihak-pihak yang terkait yang telah membantu penulis dalam menyelesaikan penelitian ini. 


\section{REFERENCES}

[1] N. Zalavadiya and S. Priyanka, "A Methodology of Malware Analysis, Tools and Technique for Windows Platform - RAT Analysus," 2017.

[2] S. C. Y. Hutauruk, F. A. Yulianto and G. B. Satrya, "Malware Analysis Pada Windows Operating System Untuk Mendeteksi Trojan," e-Proceding of Enggineering, vol. III, no. 2, pp. 35903595, 2016.

[3] R. Adenansi and L. A. Novarina, "Malware Dynamic," JOEICT (Jurnal of Education and Information Communication Technology), vol. 1 , no. 1, p. 37, 2017.

[4] D. R. Septani, N. Widiyasono and H. Mubarok, "Investigasi Serangan Malware Njrat Pada PC," Jurnal Edukasi dan Penelitian Informatika (JEPIN), vol. II, no. 2, pp. 123-128, 2016.

[5] T. A. Cahyanto, V. Wahanggara and D. Ramadana, "Analisis dan Deteksi Malware Menggunakan Metode Analisis Dinamis," JUSTINDO, Jurnal Sistem \& Teknologi Informasi Indonesia , vol. II, no. 1, pp. 19-30, 2017.

[6] U. K. Bavishi and B. M. Jain, “Malware Analysis," International Journals of Advanced Research in Computer Science and Software Engineering, vol. VII, no. 12, pp. 27-33, 2017.

[7] D. Uppal , V. Mehra and V. Verma, "Basic on Malware Analysis, Tools, and Technique," International Journal on Computational Sciences \& Applications (IJCSA) Vol.4, No.1, pp. 103-112, 2014.

[8] A. H. Muhammad, B. Sugiantoro and A. Luthfi, "Metode Klasifikasi dan Analisis Karakteristik Malware Menggunakan Konsep Ontologi," Tenomatika, vol. IX, no. 2, pp. 16-28, 2017.

[9] H. A. Nugroho and Y. Prayudi, "Penggunaan Teknik Reverse Engineering Pada Malware Analysis Untuk Identifikasi Serangan Malware," KNSI 2014, 27-28 Februari 2015, STMIK Dipanegara Makasar, pp. 1-8, 2015.

[10] Proofpoint Staff, "Proofpoint," 7 Maret 2018. [Online]. Available: https://www.proofpoint.com/us/threat-insight/post/leaked-sourcecode-ammyy-admin-turned-flawedammyy-rat.

[11] K. Sheridan, "Darkreading," 12 Maret 2018. [Online]. Available: https://www.darkreading.com/endpoint/flawedammyy-ratcampaign-puts-new-spin-on-old-threat/d/d-id/1331248.

[12] A. Saraswat, "Hacking, Hacking Tools, Vulnerability," 10 Maret 2018. [Online]. Available: https://professionalhackers.in/beware-offlawedammyy-rat-that-steals-credentials-and-record-audio-chat/.

[13] K. Ki-Su, S. Hyo-Jeong and K. Hyong-Shik, "A Bit Vector Based Binary Code Comparison Method for Static Malware Analysis," Journal of Computers, vol. xiii, no. 5, pp. 545-554, 2018.

[14] A. Zimba, L. Simukonda and M. Chishimba, "Demystifying Ransomware Attacks: Reverse Engineering and Dynamic Malware Analysis of WannaCry for Network and Information Security," ZAMBIA INFORMATION COMMUNICATION TECHNOLOGY (ICT) JOURNAL, vol. i, no. 1, pp. 35-40, 2017.

[15] B. Thakar and C. Parekh, "Reverse Engineering of Bonet (APT)," Information and Communication Technology for Intelligent Systems, vol. ii, no. 1, pp. 252-262, 2017.

[16] T. P. Setia, N. Widiyasono and A. P. Aldya, "Analisis Malware Falwed Ammyy RAT Dengan Metode Reverser Engineering," Jurnal Pengembangan IT (JPIT), pp. 371-380, 2018. 